\title{
Preparation and characterization of Protein A-immobilized PVDF and PES membranes
}

\author{
N. Akashi $^{1 *}$, S. Kuroda ${ }^{2}$ \\ ${ }^{1}$ Graduate School of Engineering, Gunma University 29-1 Hon-cho, Ohta, Gunma 373-0057, Japan \\ ${ }^{2}$ Faculty of Science and Technology, Gunma University 29-1 Hon-cho, Ohta, Gunma 373-0057, Japan
}

Received 15 May 2014; accepted in revised form 29 July 2014

\begin{abstract}
Polyvinylidene fluoride (PVDF) and polyether sulfone (PES) membranes were activated using low-temperature plasma at atmospheric pressure, and their surface characteristics were investigated. In the plasma-treated PVDF, the XPS data showed that defluorination and oxidation reactions proceeded to 18 and $31 \%$, respectively, at $\pm 4.0 \mathrm{kVp}-\mathrm{p}$ for $180 \mathrm{~s}$. Hydroperoxide groups were detected on both the plasma-treated membranes. By decomposing the S2p spectrum, it was proven that the sulfide and sulfo groups were newly formed on the plasma-treated PES. Based on these findings, we proposed an activation mechanism. The SEM images showed that the macrovoid formations were maintained after the plasma treatment. Polyacrylic acid (PAA) was grafted on both of the plasma-treated membranes by thermal treatments. Protein A, originating from Staphylococcus aureus, was immobilized on the membrane grafted with PAA using the EDC/Sulfo-NHS system. Adsorption isotherms with a human immunoglobulin $\mathrm{G}(\mathrm{IgG})$ antibody were fitted with the monolayer Langmuir model, and the maximum binding capacity $\left(q_{\mathrm{m}}\right)$ and equilibrium association constant $\left(K_{\mathrm{a}}\right)$ were obtained. The ligand densities of the PVDF (pore size 0.45 and $5.0 \mu \mathrm{m}$ ) and PES (pore size $0.45 \mu \mathrm{m}$ ) membranes were $0.98,1.42 \mathrm{and} 2.06 \mathrm{mg} \cdot \mathrm{mL}^{-1}$, respectively.
\end{abstract}

Keywords: polymer membranes, PVDF, PES, Protein A, plasma

\section{Introduction}

Fluoropolymers have excellent features, such as electrical and chemical resistance, high thermal stability and low surface energies [1]. Fluorinated polymers are applied in many industries, such as for thin film technology magnetic media, non-stick cookware and engineering plastics [2]. One of the commercially available fluoropolymers is polyvinylidene fluoride (PVDF). Research and application of PVDF membranes has been reported since the 1980s [3]. One of the reasons for this is that PVDF dissolves in common organic solvents, so porous PVDF membranes can be produced via phase inversion methods with a simple immersion precipitation process. On the other hand, polyether sulfone (PES) has also been widely available commercially, and has excel- lent mechanical strength and is a thermally stable polymer [4]. Thus, PES membranes have been adopted as important materials in the food, hemodialysis and water purification fields, as well as for biopharmaceutical drugs as microfiltration (MF) and ultrafiltration (UF) [5]. PES and PVDF membranes are valuable as research subjects in separation fields. However, PVDF and PES have the issue of being intrinsically and severely hydrophobic [6]. As the result, proteins dissolved in aqueous solutions tend to clog the membranes. Therefore, manufacturers provide membranes that are hydrophilized to decreasing the nonspecific protein binding capacity with various surface modifications to prevent objective substances, such as recombinant proteins, from fouling the membranes $[7,8]$. Other advancements

\footnotetext{
${ }^{*}$ Corresponding author, e-mail: akashi.n@jcom.home.ne.jp (C) BME-PT
} 
in the field have been related to pore size distributions and membrane types, which are critical factors to achieve anti-fouling properties, and deal with variations at the production scale. High capacity membranes have been developed for the biotechnology industry with varying pore size distributions, such as isotropic and anisotropic structures [9].

In recent years, many functionalized membranes with surface modifications have been reported [1012]. There has been significant interest in using affinity membrane chromatography for bioprocessing, but few reports are applied in production scales because the adsorption capacities of the affinity membranes are relatively low compared with those for conventional bead chromatography [13]. Humanized monoclonal antibodies (mAbs), which belong to a subclass of $\operatorname{IgG}$, have been utilized in clinical fields as drug products [14]. To capture mAbs efficiently from the pool of the mAb production, Protein $\mathrm{A}$ is widely applied as a ligand on affinity chromatography media because Protein A strongly binds on the Fc region of IgG [15]. However, native Protein A originates from Staphylococcus aureus [9]. Therefore, it is important to establish a method for immobilizing Protein A on the media because of the decrease in the amount of leached Protein A. Simultaneously, a media with good chemical resistance and thermally stable features should be selected. As such, PVDF and PES membranes are important candidates as affinity media.

Plasma processing is a dry process for clean and energy saving surface modifications $[16,17]$. Compared to plasma processing with a vacuum, atmospheric pressure low-temperature plasma does not need equipment for vacuum processing [18]. Plasma induced free radical polymerization is a useful technique for grafting polymers to hydrophilize or functionalize the surface of a polymeric substrate [19]. On the other hand, surface modifications on hydrophilic PVDF membranes have also been reported to have a covalent coupling of lysine as model of biologically active molecules [20]. It is highly plausible to minimize nonspecific adsorption on the membrane because the protein adsorption capacity of hydrophobic and hydrophilic PVDF membranes varies significantly, reportedly from 1157 and $84 \mathrm{mg} \cdot \mathrm{m}^{-2}$ [21].

The first goal of our study was to reveal the activation mechanism of PVDF and PES membranes activated by atmospheric pressure low-temperature plasma. The surface chemicals and morphological properties of the membranes were characterized by attenuated total reflection (ATR), Fourier transform infrared (FT-IR) spectroscopic analysis, scanning electron microscopy (SEM) and X-ray photoelectron spectroscopy (XPS). The second goal of our study was to characterize the properties of Protein A-immobilized PVDF and PES membranes. The adsorption capacities with human IgG were confirmed according to the monolayer Langmuir model [22], and the ligand density on the membranes was also measured using a bicinchoninic acid (BCA) protein assay [23].

\section{Experimental}

\subsection{Materials}

PVDF (Durapore ${ }^{\circledR}$, hydrophilic) membranes were purchased from Merck Millipore Corp. (Darmstadt, Germany), commercially named HVLP01300 (pore size $0.45 \mu \mathrm{m}$ ) and SVLP01300 (pore size $5.0 \mu \mathrm{m}$ ). A PES membrane (Millipore Express ${ }^{\circledR}$ PLUS) was also purchased from Merck Millipore Corp., commercially named HPWP01300 (pore size $0.45 \mu \mathrm{m}$ ). Protein A from Staphylococcus aureus was purchased from Calbiochem (Darmstadt, Germany). $N$-Hydroxysulfosuccinimide (Sulfo-NHS), 1-(3Dimethylaminopropyl)-3-ethylcarbodiimide (EDC) $\mathrm{HCl}, 2$ ( $N$-morpholino) ethanesulfonic acid (MES) and hydroxylamine $\mathrm{HCl}$ were purchased from ProteoChem, Inc. (IL, United States). An acrylic acid (AA) monomer and IgG from human serums were purchased from Sigma-Aldrich, Inc. (MO, United States). AA was distilled in a nitrogen atmosphere prior to use. The Micro BCA protein assay kit was purchased from Thermo Fisher Scientific Inc. (MA, United States). PBS (-) was purchased from Nissui Pharmaceutical Co., Ltd (Tokyo, Japan). The purity of the argon gas used was in excess of $99.99 \%$.

\subsection{Plasma reactor}

The plasma reactor consists of a high frequency pulse power supply, a gas supply unit and a cold atmospheric pressure plasma torch (CAPPLAT). The CAPPLAT has a cylindrical structure in which the plasma is generated. The plasma is blown out through the end of the CAPPLAT, which consists of two co-axial cylindrical electrodes. The inner electrode, a copper tube (OD: $8 \mathrm{~mm}$, ID: $7 \mathrm{~mm}$ ), is connected to the power supply. The outer electrode (thickness: $1 \mathrm{~mm}$, length: $20 \mathrm{~mm}$ ) is made of alu- 
minum and grounded. As a dielectric barrier, a silicone tube (thickness: $2.5 \mathrm{~mm}$ ) is placed between the two electrodes. The outlet of the CAPPLAT is embedded in the edge of a perforated silicone tube.

\subsection{Preparation of the PVDF and PES membranes immobilized with Protein A}

Figure 1 shows a schematic illustration of the preparation for the PVDF/PES membranes immobilized with Protein A. Prior to the surface modification experiment, the membranes were rinsed with ethanol and dried at room temperature. For plasma treatment of the membranes, argon gas was fed into the CAPPLAT at a flow rate of $5 \mathrm{~L} \cdot \mathrm{min}^{-1}$, and the plasma was generated under an applied voltage of $\pm 4 \mathrm{kVp}$ - $\mathrm{p}$, frequency of $20 \mathrm{kHz}$, treatment time of $180 \mathrm{~s}$ and a duty cycle of $50 \%$. The membranes were treated with plasma $20 \mathrm{~mm}$ away from the torch end. Subsequently, the membranes were exposed to air for $20 \mathrm{~min}$ at $35^{\circ} \mathrm{C}$. The air-exposed membranes were immersed in an aqueous solution containing 20\% $(\mathrm{v} / \mathrm{v})$ of AA monomer. After bubbling with nitrogen for $20 \mathrm{~min}$ to remove dissolved oxygen, the ampoules were sealed and heated at $70^{\circ} \mathrm{C}$ to initiate graft polymerization. The PVDF and PES membranes grafted with polyacrylic acid (hereafter called PVDF-gPAA and PES-g-PAA, respectively or PVDF/PESg-PAA) were rinsed with distilled water to remove non-grafted monomers. Protein A was immobilized on the PVDF/PES-g-PAA membranes using the EDC/Sulfo-NHS method. The membranes were activated with a $4 \mathrm{mmol} \cdot \mathrm{L}^{-1} \mathrm{EDC}, 10 \mathrm{mmol} \cdot \mathrm{L}^{-1}$ Sulfo-NHS in $100 \mathrm{mmol} \cdot \mathrm{L}^{-1} \mathrm{MES}, 500 \mathrm{mmol} \cdot \mathrm{L}^{-1}$
$\mathrm{NaCl}$ buffer solution with a $\mathrm{pH}$ of 6.0 for $15 \mathrm{~min}$ at room temperature. The immobilization of Protein A was carried out in a solution of $1 \mathrm{mg} \cdot \mathrm{mL}^{-1}$ Protein A in $100 \mathrm{mmol} \cdot \mathrm{L}^{-1} \mathrm{MES}, 500 \mathrm{mmol} \cdot \mathrm{L}^{-1} \mathrm{NaCl}$ buffer with a $\mathrm{pH}$ of 6.0 under mild agitation for $3.0 \mathrm{~h}$ at room temperature. The immobilization reaction of the PVDF and PES membranes (hereafter called PVDF-g-PAA-PrA and PES-g-PAA-PrA, respectively or PVDF/PES-g-PAA-PrA) was quenched by adding hydroxylamine $\mathrm{HCl}$ to give a final concentration of $10 \mathrm{mmol} \cdot \mathrm{L}^{-1}$. The membranes were rinsed with a solution of PBS (-) to remove loosely absorbed Protein A and the MES buffer solution, and then kept in a solution of PBS $(-)$ at $5^{\circ} \mathrm{C}$.

\subsection{ATR FT-IR measurement}

ATR FT-IR spectroscopic investigations were carried out with a Nicolet iS10 spectrometer (Thermo Fisher Scientific Inc.) using a Ge crystal. The spectra were collected by cumulating 64 scans at a resolution of $2 \mathrm{~cm}^{-1}$.

\subsection{XPS measurement}

XPS was performed on a Kratos AXIS Nova spectrometer (Manchester, United Kingdom) using a monochromatized Al Ka X-ray source $(1486.6 \mathrm{eV}$ photons). All measurements were made at a photoelectron takeoff angle of $45^{\circ}$. High resolution analyses were carried with a constant dwell time of $200 \mathrm{~ms}$, pass energy of $20 \mathrm{eV}$ and an energy resolution of $0.1 \mathrm{eV}$. All binding energies (BEs) were referenced to the $\mathrm{C} 1 \mathrm{~s}$ hydrocarbon peak at $286.4 \mathrm{eV}$. Spectra were analyzed using XPSPEAK software

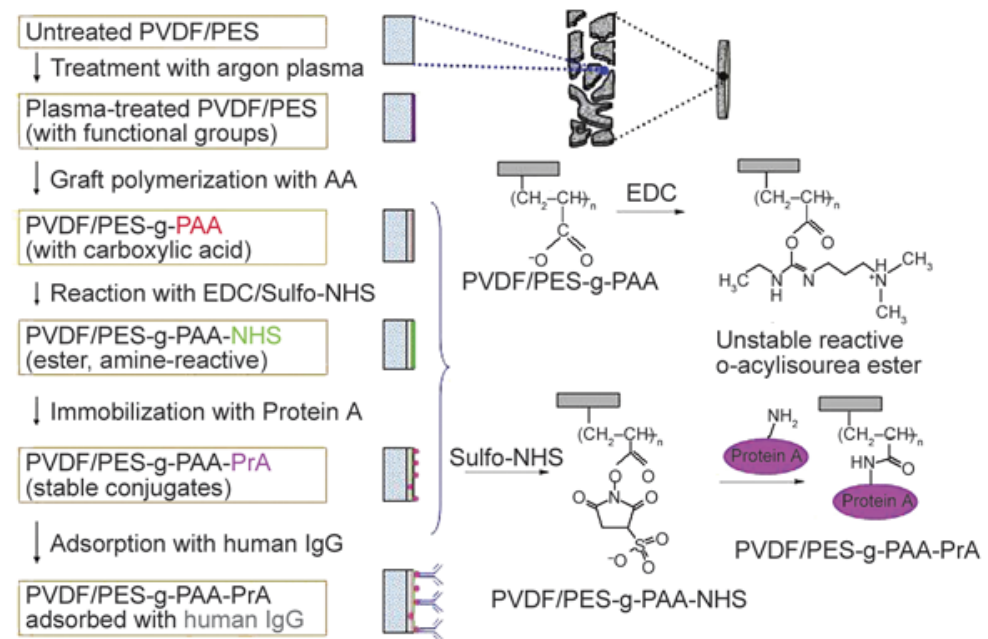

Figure 1. Schematic illustration of the preparation for the PVDF and PES membranes immobilized with Protein A and the adsorption with human IgG 
(version 4.1). Curve fitting of the high resolution spectra used 30\% Gaussian $/ 70 \%$ Lorentzian mixed line shapes for each component.

\subsection{Determination of adsorption capacities}

The nonspecific adsorption on the PVDF/PES-gPAA membranes and the adsorption isotherm on the PVDF/PES-g-PAA-PrA membranes with a human $\mathrm{IgG}$ were measured. Four of the membranes were employed in each closed glass vessel. The membranes were equilibrated in a solution of PBS (-) at a $\mathrm{pH}$ of 7.4 as an equilibrium buffer solution for $10 \mathrm{~min}$. The equilibrium buffer solution was replaced with $4 \mathrm{~mL}$ of the equilibrium buffer solution dissolved with different concentrations of human IgG, and incubated for $12 \mathrm{~h}$ at $20^{\circ} \mathrm{C}$. The amount of human $\mathrm{IgG}$ adsorbed on the membranes was determined by measuring the concentration of human IgG before and after the adsorption experiments were performed. Each concentration of human IgG was measured by a Micro BCA protein assay. The adsorption isotherms were constructed by plotting the adsorption capacity on the membranes versus the equilibrium concentration of human $\mathrm{IgG}$ dissolved in the liquid. Data were analyzed according to the monolayer Langmuir model shown in Equation (1):

$q^{*}=\frac{q_{\mathrm{m}} \cdot K_{\mathrm{a}} \cdot c^{*}}{1+K_{\mathrm{a}} \cdot c^{*}}$

where the $c^{*}$ and $q^{*}$ represented the equilibrium concentration of the human IgG dissolved in the liquid and the equilibrium capacity of human $\operatorname{IgG}$ adsorbed on the membranes, respectively. The variable $q_{\mathrm{m}}$ represented the maximum adsorption capacity on the membranes and $K_{\mathrm{a}}$ represented the equilibrium association constant. Equation (1) was transformed into a linear form as a double reciprocal plot, shown in Equation (2), to calculate $q_{\mathrm{m}}$ and $K_{\mathrm{a}}$ :

$\frac{1}{q^{*}}=\frac{1}{q_{\mathrm{m}}}+\frac{1}{K_{\mathrm{a}} \cdot q_{\mathrm{m}}} \cdot \frac{1}{c^{*}}$

where the $q^{*}$ and $q_{\mathrm{m}}$ were calculated in $\mathrm{mg} \cdot \mathrm{mL}^{-1}$, which represents the weight of human IgG adsorbed per volume of the membrane. Variable $K_{\mathrm{a}}$ was calculated in $\mathrm{L} \cdot \mathrm{mol}^{-1}$ by considering the molecular weight to be $146 \mathrm{kDa}$ [24].

\subsection{Determination of ligand densities}

The amount of Protein A covalently immobilized on each PVDF/PES-g-PAA-PrA membrane was meas- ured with a BCA protein assay [13]. The ligand density was calculated in $\mathrm{mg} \cdot \mathrm{mL}^{-1}$, which represents the weight of Protein A immobilized per volume of the membrane.

\subsection{Procedure of stability test}

The PVDF/PES-g-PAA-PrA membranes were treated by repeating the cycle of equilibration, adsorption, elution, washing and regeneration to estimate the stability of the membranes. Four membranes were employed in each closed glass vessel. First, the membranes were equilibrated by a solution of PBS $(-)$ at a $\mathrm{pH}$ of 7.4 as an equilibrium buffer solution for $10 \mathrm{~min}$ (equilibration), and then replaced in $4 \mathrm{~mL}$ of the equilibrium buffer solution dissolved $0.1 \mathrm{mg} \cdot \mathrm{mL}^{-1}$ human $\mathrm{IgG}$ for $10 \mathrm{~min}$ (adsorption). Secondly, the membranes were immersed in $4 \mathrm{~mL}$ of $0.1 \mathrm{~mol} \cdot \mathrm{L}^{-1}$ citric acid buffer solution at a $\mathrm{pH}$ of 3.0 for $10 \mathrm{~min}$ (elution), and then washed with a solution of PBS (-) at a $\mathrm{pH}$ of 7.4 for $10 \mathrm{~min}$ (washing). Finally, the membranes were immersed in $20 \%(\mathrm{v} / \mathrm{v})$ ethanol for $20 \mathrm{~min}$ (regeneration). After the five cycles were performed, the ligand densities of the membranes were measured.

\subsection{SEM measurement}

The surface and cross-section morphologies of the membranes were examined by SEM, using a Hitachi S-3000N electron microscope (Tokyo, Japan). A thin layer of Pt was sputtered on the sample surface prior to the SEM measurement. The SEM measurements were performed at an accelerating voltage of $15.0 \mathrm{kV}$.

\section{Results and discussion}

\subsection{Structure characterization of the membranes by ATR-FTIR analysis}

Figure 2 shows the respective ATR-FTIR spectra of PES membrane and represented the data of the membranes untreated, treated with argon plasma, grafted with AA and those immobilized with the Protein A. The ATR-FTIR spectra of the PVDF membranes were similar to those in the previous report [19]. The strong absorption bands at $1107-1240 \mathrm{~cm}^{-1}$ were characteristic bands of aromatic ethers and sulfonyl groups of PES (Figure 2 curve a). The spectrum of the plasma-treated PES membrane contained a weak absorption band at approximately $1700 \mathrm{~cm}^{-1}$ (Figure 2 curve b). The spectrum of the PES-g-PAA membrane appeared with a strong car- 


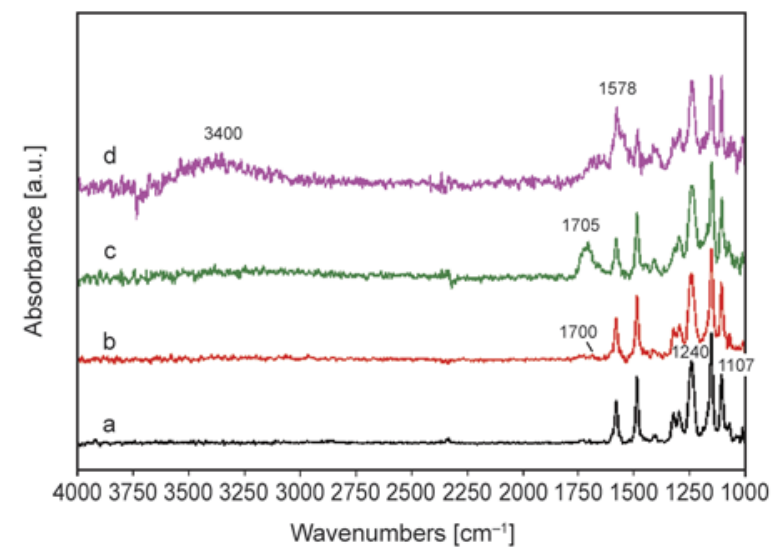

Figure 2. ATR-FTIR spectra of PES membranes. (a) untreated, (b) treated with argon plasma (treatment: $\pm 4.0 \mathrm{kVp}-\mathrm{p}, 180 \mathrm{~s}$ ), (c) grafted with AA (treatment: $\left.20 \%(\mathrm{v} / \mathrm{v}) \mathrm{AA}, 70^{\circ} \mathrm{C}, 20 \mathrm{~min}\right)$ and (d) immobilized with Protein A (treatment: $1 \mathrm{mg} \cdot \mathrm{mL}^{-1}, 3 \mathrm{~h}$ )

bonyl $(\mathrm{C}=\mathrm{O})$ stretching absorption band at $1705 \mathrm{~cm}^{-1}$ (Figure 2 curve $\mathrm{c}$ ). This indicates that polyacrylic acid chains were successfully grafted on the membrane. The spectrum of the PES-g-PAA-PrA membrane revealed the increase of the absorption band attributed to the $\mathrm{NH}$-deformation vibration at $1578 \mathrm{~cm}^{-1}$, and broad absorption bands attributed to primary amino groups with a maximum at $3400 \mathrm{~cm}^{-1}$ were strongly observed (Figure 2 curve d). Consequently, it was demonstrated that Protein A was successfully immobilized on the PES-g-PAA membrane.

\subsection{Structure characterization of the membranes by XPS analysis}

We investigated the influence of defluorination and oxidation on the plasma treatment time and applied voltage compared with untreated PVDF membranes. The atomic composition was estimated from relative intensities of $\mathrm{C} 1 \mathrm{~s}, \mathrm{~F} 1 \mathrm{~s}, \mathrm{O} 1 \mathrm{~s}, \mathrm{~N} 1 \mathrm{~s}$ and $\mathrm{S} 2 \mathrm{p}$ high resolution spectra. Atomic ratios of the PVDF and PES samples are summarized in Tables 1 and 2, respectively.

The $\mathrm{F} / \mathrm{C}$ and $\mathrm{O} / \mathrm{C}$ atom ratios of the untreated PVDF membrane were individually 0.72 and 0.13 due to the hydrophilic treatment from the manufacturer. In the case of the plasma-treated PVDF membranes, the defluorination reactions proceeded 18 , 18 and $24 \%$ for 60,180 and 300 s of plasma exposure time, respectively. Secondly, the degree of defluorination resulted in 7,18 and $18 \%$ at $\pm 2.8, \pm 4.0$ and $\pm 5.0 \mathrm{kVp}$-p, respectively. The sample treated at $\pm 5.0 \mathrm{kVp}$-p was appeared to have an intensively
Table 1. Atomic ratios of the PVDF membrane (pore size $0.45 \mu \mathrm{m}$ ) surfaces exposed to argon plasma (treatment: flow rate of argon gas at $5 \mathrm{~L} \cdot \mathrm{min}^{-1}$ )

\begin{tabular}{|c|c|c|c|c|c|}
\hline \multicolumn{2}{|c|}{ Plasma treatment } & \multicolumn{2}{|c|}{ Atomic ratio } & \multirow[b]{2}{*}{$\begin{array}{c}\text { Defluori- } \\
\text { nation } \\
{[\%]}\end{array}$} & \multirow[b]{2}{*}{$\begin{array}{c}\text { Oxidation } \\
{[\%]}\end{array}$} \\
\hline $\begin{array}{c}\text { Voltage } \\
{[ \pm k V p-p]}\end{array}$ & $\begin{array}{c}\text { Exposure } \\
\text { time } \\
{[\mathbf{s}]} \\
\end{array}$ & $\mathbf{F} / \mathbf{C}$ & $\mathrm{O} / \mathrm{C}$ & & \\
\hline- & - & 0.72 & 0.13 & 0 & 0 \\
\hline 4.0 & 60 & 0.59 & 0.16 & 18 & 23 \\
\hline 4.0 & 180 & 0.59 & 0.17 & 18 & 31 \\
\hline 4.0 & 300 & 0.55 & 0.20 & 24 & 54 \\
\hline 2.8 & 180 & 0.67 & 0.18 & 7 & 38 \\
\hline 4.0 & 180 & 0.59 & 0.17 & 18 & 31 \\
\hline 5.0 & 180 & 0.59 & 0.20 & 18 & 54 \\
\hline
\end{tabular}

Table 2. Atomic ratios of the PES membrane surfaces exposed to argon plasma (treatment: flow rate of argon gas at $5 \mathrm{~L} \cdot \mathrm{min}^{-1}$ )

\begin{tabular}{|c|c|c|c|c|}
\hline \multicolumn{2}{|c|}{ Plasma treatment } & \multicolumn{2}{|c|}{ Atomic ratio } & \multirow{2}{*}{$\begin{array}{c}\text { Oxidation } \\
{[\%]}\end{array}$} \\
\hline $\begin{array}{l}\text { Voltage } \\
{[ \pm k V p-p]}\end{array}$ & $\begin{array}{c}\text { Exposure time } \\
{[\mathrm{s}]}\end{array}$ & $\mathbf{O} / \mathrm{C}$ & $\mathrm{S} / \mathrm{C}$ & \\
\hline- & - & 0.37 & 0.049 & 0 \\
\hline 4.0 & 60 & 0.50 & 0.087 & 35 \\
\hline 4.0 & 180 & 0.66 & 0.075 & 78 \\
\hline 4.0 & 300 & 0.77 & 0.064 & 108 \\
\hline 2.8 & 180 & 0.54 & 0.069 & 46 \\
\hline 4.0 & 180 & 0.66 & 0.075 & 78 \\
\hline 5.0 & 180 & 0.78 & 0.110 & 111 \\
\hline
\end{tabular}

burnt area, so it was presumed to lead to heavy etching reactions. In a recent related report of the argon plasma treatment to other fluoropolymers, Hidzir et al. [25] described that the chemical environment of the surface of expanded poly (tetrafluoroethylene), which was treated with $100 \mathrm{~W}$ argon plasma under the low pressure and subsequently exposed to air changed substantially, displayed evidence of defluorination ( $\mathrm{F} / \mathrm{C}$ atom ratio of 1.9 from 2.4). On the other hand, oxidation reactions progressed 23, 31 and 54\% for 60, 180 and $300 \mathrm{~s}$, respectively, compared with an untreated PVDF membrane. Moreover, the degree of oxidation was 38 , 31 and $54 \%$ at $\pm 2.8, \pm 4.0$ and $\pm 5.0 \mathrm{kVp}$-p. These data imply that the oxygen functional groups, such as peroxide species, were generated on the plasmatreated PVDF membrane.

The $\mathrm{O} / \mathrm{C}$ and $\mathrm{S} / \mathrm{C}$ atom ratios of the untreated PES membrane were 0.37 and 0.049 , respectively, due to the hydrophilic treatment. In the case of the plasmatreated PES membranes, the oxidation reactions proceeded 35, 78 and $108 \%$ for 60,180 and $300 \mathrm{~s}$, respectively. Secondly, the degree of oxidation was 46,78 and $111 \%$ at $\pm 2.8, \pm 4.0$ and $\pm 5.0 \mathrm{kVp}$-p, 

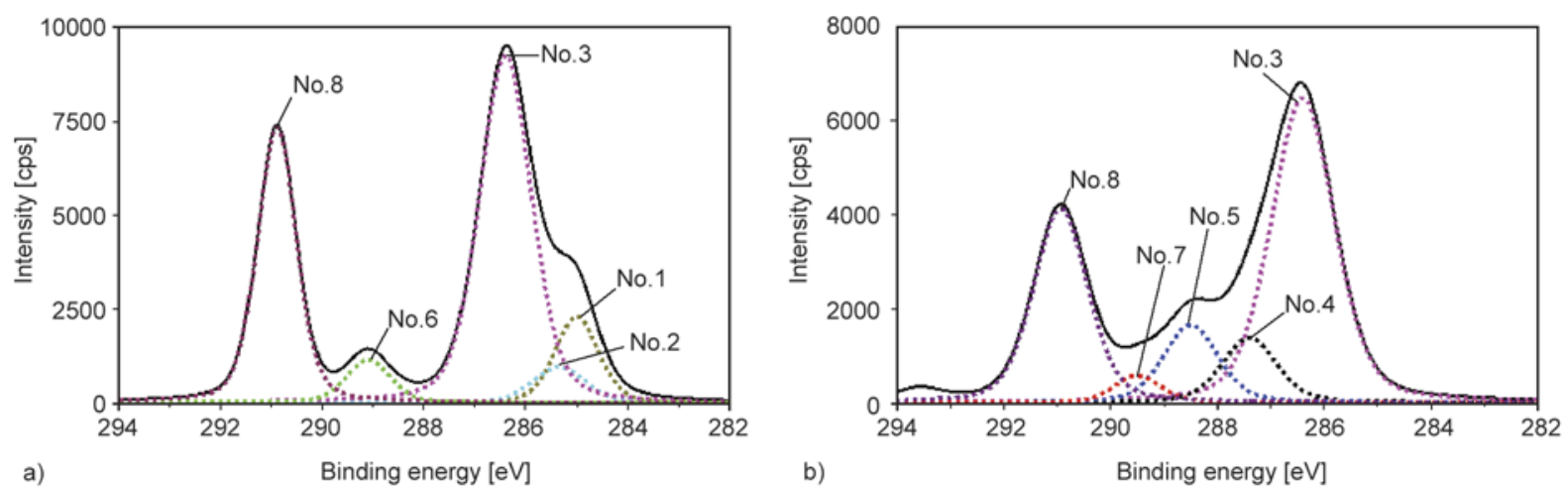

Figure 3. High resolution XPS spectra of C1s. (a) untreated PVDF (pore size $0.45 \mu \mathrm{m}$ ) membrane and (b) PVDF membrane treated with argon plasma (treatment: $\pm 4.0 \mathrm{kVp}-\mathrm{p}, 180 \mathrm{~s}$ ).

respectively. Moreover, the oxidation reaction on the PES membranes progressed approximately two times higher than that of the PVDF membranes. These findings suggest that the plasma-treated PES membrane has more initiation sites for graft polymerization relative to the plasma-treated PVDF membrane.

Figure 3 shows $\mathrm{C} 1 \mathrm{~s}$ high resolution spectra for the untreated PVDF membrane and plasma-treated PVDF membrane. The decomposed peaks are illustrated as dotted lines. The underlined $\mathrm{C}, \mathrm{O}$ or $\mathrm{S}$ means the objective was carbon, oxygen or sulfur, respectively.

The $\mathrm{C} 1 \mathrm{~s}$ high resolution spectrum of the untreated PVDF membrane was assigned to five peaks at BEs of $285.0 \mathrm{eV}$ due to $\mathrm{CH}(\mathrm{COOH})-\mathrm{CH}_{2}-\mathrm{CH}(\mathrm{COOH})$ : No. $1,285.4 \mathrm{eV}$ due to $\underline{\mathrm{C}} \mathrm{H}-\mathrm{COOH}$ : No. $2,286.4 \mathrm{eV}$ due to $\mathrm{CF}_{2}-\mathrm{CH}_{2}-\mathrm{CF}_{2}$ : No. 3, $289.1 \mathrm{eV}$ due to $\mathrm{CH}-$ COOH: No. 6 and $290.9 \mathrm{eV}$ due to $\mathrm{CH}_{2}-\mathrm{CF}_{2}-\mathrm{CH}_{2}$ : No. 8 (Figure 3a). These data indicate that the untreated PVDF membrane is cross-linked with hydroxyalkyl acrylate to hydrophilize the membrane [7]. The C1s high resolution spectrum of the plasma-treated PVDF membrane was decomposed into five peaks (Figure 3b) [19]. The five peaks appeared at BEs of 286.4, 287.4, 288.5, 289.5 and $290.9 \mathrm{eV}$, which were assigned to $\mathrm{CF}_{2}-\mathrm{CH}_{2}-\mathrm{CF}_{2}$, $\mathrm{CH}_{2}-\underline{\mathrm{CF}}=\mathrm{CH}, \mathrm{CH}_{2}-\underline{\mathrm{CF}}=\mathrm{CH}_{2}$ and hydroperoxide $\left(\mathrm{CH}_{2}-\mathrm{CH}(-\mathrm{OOH})-\mathrm{CH}_{2}\right)$ groups (No. 3); hydroperoxide $\left(\mathrm{CF}_{2}-\mathrm{CH}(-\mathrm{OOH})-\mathrm{CF}_{2}\right)$ (No. 4); carbonyl $\left(\mathrm{CF}_{2}-\underline{\mathrm{CHO}}\right.$ ) and $\mathrm{CH}_{2}-\underline{\mathrm{C} F H}-\mathrm{CH}_{2}$ groups (No. 5); hydroperoxide $\left(\mathrm{CH}_{2}-\underline{\mathrm{CF}}(-\mathrm{OOH})-\mathrm{CH}_{2}\right)$ (No. 7); and $\mathrm{CH}_{2}-\underline{\mathrm{CF}}_{2}-\mathrm{CH}_{2}$ and carbonyl $\left(\mathrm{CH}_{2}-\underline{\mathrm{C}} \mathrm{FO}\right)$ and $\mathrm{CH}=\mathrm{CF}_{2}$ groups (No. 8), respectively. The composition showed that $\mathrm{CF}_{2}$ carbons were modified into $\underline{\mathrm{CFH}}, \underline{\mathrm{C}}(-\mathrm{OOH})$ and $\underline{\mathrm{CFO}}$ carbons in the plasma exposure. Lee and Shim have measured the concen- tration of peroxides formed on the argon plasmatreated PVDF membranes (pore size $0.22 \mu \mathrm{m}$ and $70 \%$ porosity) by the 1,1-diphenyl-2-picrylhydrazyl (DPPH) method [26]. The density of peroxides showed $2.5 \cdot 10^{-8} \mathrm{~mol} \cdot \mathrm{cm}^{-2}$ at $30 \mathrm{~W}$ for $30 \mathrm{~s}$ in 50 mTorr. Although the density increased until the $30 \mathrm{~s}$ exposure, interestingly, it decreased with a $40 \mathrm{~s}$ exposure. These data suggested that the $\mathrm{C} 1 \mathrm{~s}$ high resolution spectrum shape of the plasma-treated PVDF membrane as shown in Figure 3 was dependent on the exposure conditions.

The C1s high resolution spectrum of the PVDF-gPAA membrane was decomposed into three characteristic peaks attributable to the AA graft polymerization. The three peaks observed at BEs of 285.0, 285.4 and $289.1 \mathrm{eV}$, were individually assigned to the $\mathrm{CH}(\mathrm{COOH})-\mathrm{CH}_{2}-\mathrm{CH}(\mathrm{COOH}) ; \underline{\mathrm{C}} \mathrm{H}-\mathrm{COOH}$; and carboxy $(\mathrm{CH}-\underline{\mathrm{COOH}})$ groups.

Graft polymerization of acrylic acid is a useful method for forming many carboxy groups on the membranes to react with EDC, and subsequently results in a semi-stable amine-reactive NHS ester. In addition, Huang et al. [27] have reported that plasma induced grafting of acrylic acid significantly improved the wettability behavior of the PVDF nanofiber membranes. In this way, there are some advantages of applying the polymerization, but it is important to optimize the grafting conditions because excessive grafting leads to a decrease in the porosity and surface area of the microporous membranes with particularly small pore sizes.

We also investigated the data for $\mathrm{C} 1 \mathrm{~s}, \mathrm{O} 1 \mathrm{~s}$ and $\mathrm{S} 2 \mathrm{p}$ high resolution spectra of the PES membranes (Figure 4). The $\mathrm{C} 1 \mathrm{~s}$ and $\mathrm{O} 1 \mathrm{~s}$ high resolution spectra and percentages of each bond type on the PES-g-PAA membrane were consistent with the results of the PVDF-g-PAA membrane. 
The $\mathrm{C} 1 \mathrm{~s}$ high resolution spectrum of the untreated PES membrane was assigned to three peaks at BEs of $284.7 \mathrm{eV}$ due to aromatic $\underline{\mathrm{C}}-\underline{\mathrm{C}}$ : No. $1,285.3 \mathrm{eV}$ due to $\underline{\mathrm{C}}-\mathrm{SO}_{2}-\underline{\mathrm{C}}$ No. 2 and $286.3 \mathrm{eV}$ due to $\underline{\mathrm{C}}-\mathrm{O}-\underline{\mathrm{C}}$ and phenolic carbons that bond to hydroxy groups: No. 3 (Figure 4a). The $\pi-\pi^{*}$ shake-up satellite peak was shown at $291.7 \mathrm{eV}$. The peak area ratio at $286.3 \mathrm{eV}$ (No. 3) was 37\%, which was higher than the theoretical value of hydrophobic PES, and the peak area ratio at $284.7 \mathrm{eV}$ (No. 1) was $44 \%$, which was lower than that of hydrophobic PES. These results suggest that the dehydrogenation and oxidation reactions of the benzene ring on the PES membrane progressed, and several phenolic carbons are constituted on the membrane [8]. Secondly, the O1s
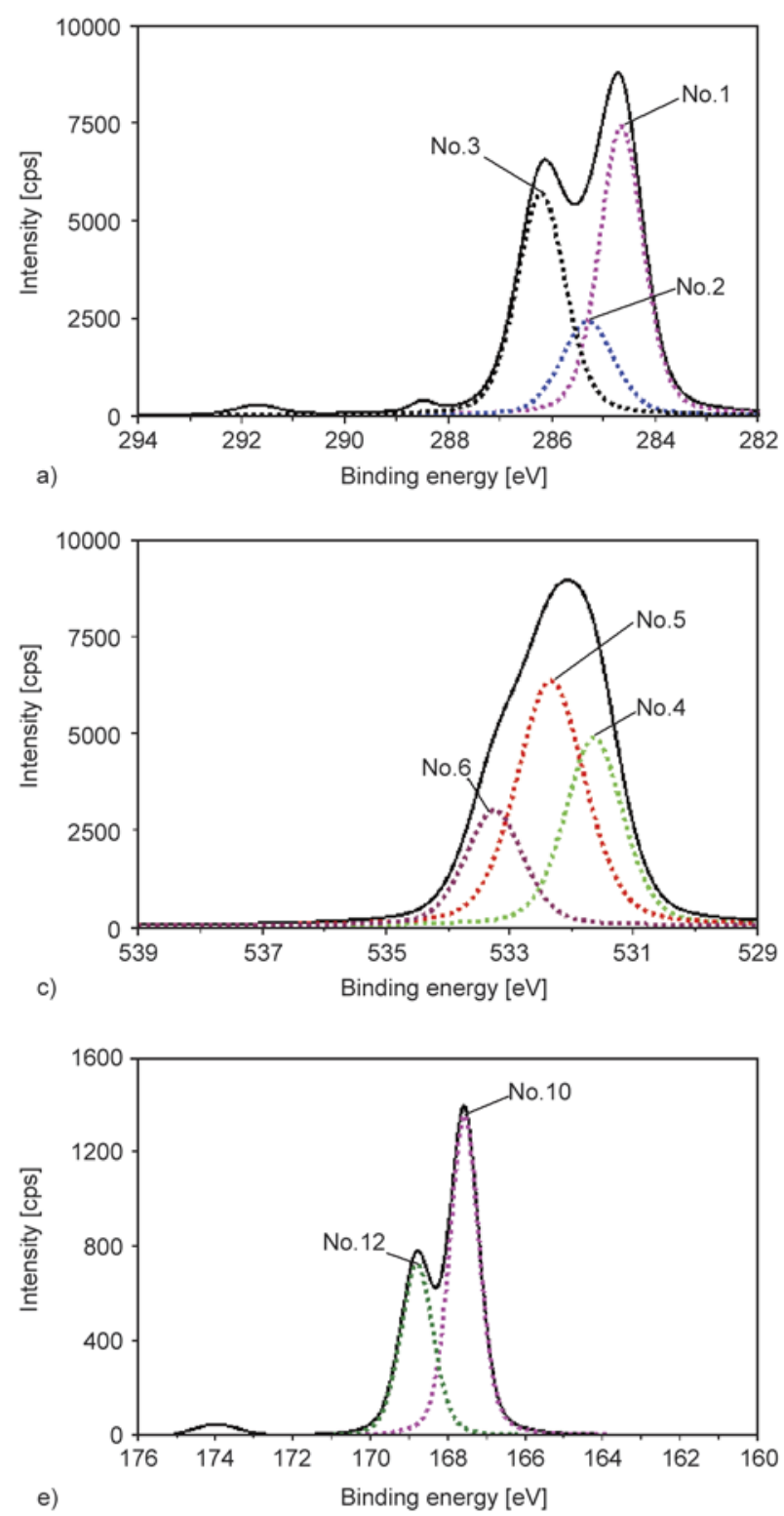

high resolution spectrum of the untreated PES membrane was deconvoluted into three peaks at BEs of $531.6 \mathrm{eV}$ due to the sulfonyl group, $\mathrm{C}-\mathrm{S} \underline{\mathrm{O}}_{2}-\mathrm{C}$ : No. 4, $532.3 \mathrm{eV}$ due to oxygen in the hydroxy group, $\mathrm{R}-\underline{\mathrm{OH}}$ : No. 5 and $533.3 \mathrm{eV}$ due to $\mathrm{C}-\underline{\mathrm{O}}-\mathrm{C}:$ No. 6 (Figure 4c). Thirdly, the S2p high resolution spectrum of the untreated PES membrane was deconvoluted into two distinct peaks at BEs of $167.6 \mathrm{eV}$ due to $\mathrm{S}_{2} \mathrm{p}_{3 / 2}$ for $\mathrm{C}-\underline{\mathrm{S}}_{2}-\mathrm{C}$ : No. 10 and $168.8 \mathrm{eV}$ due to $\mathrm{S} 2 \mathrm{p}_{1 / 2}$ for $\mathrm{C}-\mathrm{SO}_{2}-\mathrm{C}$ : No. 12 (Figure $4 \mathrm{e}$ ).

On the other hand, the $\mathrm{C} 1 \mathrm{~s}$ high resolution spectrum of the plasma-treated PES membrane was decomposed into three peaks of $284.7 \mathrm{eV}$ due to aromatic $\underline{\mathrm{C}}-\mathrm{C}$ : No. $1,285.3 \mathrm{eV}$ due to $\underline{\mathrm{C}}-\mathrm{SO}_{2}-\mathrm{C}$ : No. 2 and $286.3 \mathrm{eV}$ due to $\underline{\mathrm{C}}-\mathrm{O}-\underline{\mathrm{C}}, \underline{\mathrm{C}}-\mathrm{OH}$ and hydroperoxide
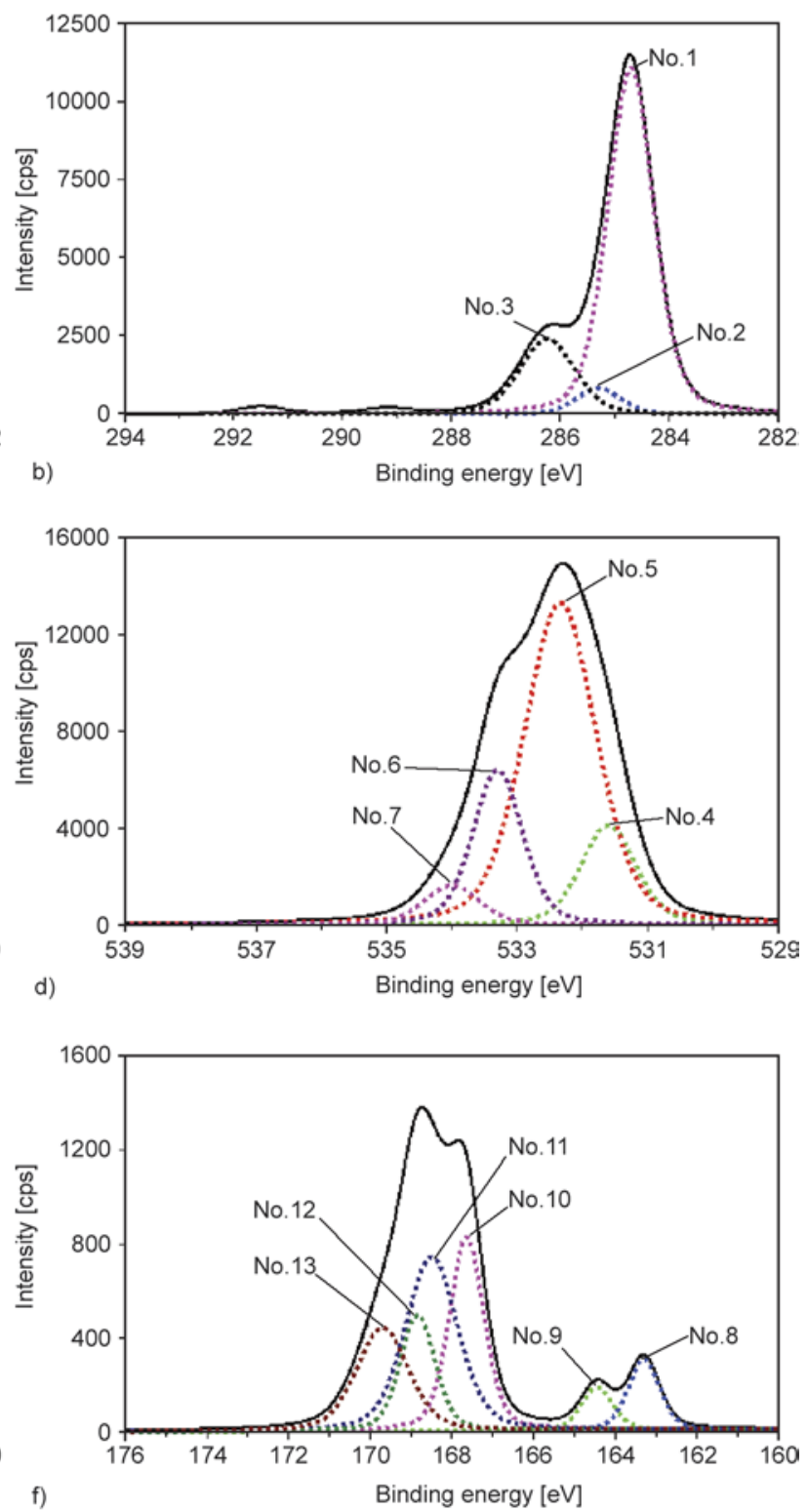

Figure 4. High resolution XPS spectra of C1s (a, b), O1s (c, d) and S2p (e, f): (a, c, e) untreated PES membrane and (b, d, f) PES membrane treated with argon plasma (treatment: $\pm 4.0 \mathrm{kVp}-\mathrm{p}, 180 \mathrm{~s}$ ) 
$(\mathrm{C}-\underline{\mathrm{CH}}(-\mathrm{OOH})-\mathrm{C})$ groups: No. 3 (Figure $4 \mathrm{~b})$. The peak area ratio of the $\pi$ - $\pi^{*}$ shake-up was $2 \%$, which was approximately the same level as that of the untreated PES membrane. Secondly, the O1s high resolution spectrum of the plasma-treated PES membrane was curve-fitted with four peaks at BEs of $531.6 \mathrm{eV}$ due to $\mathrm{C}-\mathrm{S} \underline{\mathrm{O}}_{2}-\mathrm{C}$ : No. $4,532.3 \mathrm{eV}$ due to R- $\underline{\mathrm{OH}}$ : No. 5, $533.3 \mathrm{eV}$ due to $\mathrm{C}-\underline{\mathrm{O}}-\mathrm{C}$ and $\mathrm{C}-\mathrm{CH}$ (- $-\mathrm{OOH})-\mathrm{C}:$ No. 6 , and $534.0 \mathrm{eV}$ for hydroperoxide R-O H H: No. 7 (Figure 4d). Finally, the S2p high resolution spectrum of the plasma-treated PES membrane was deconvoluted into six peaks at BEs of $163.3 \mathrm{eV}$ due to $\mathrm{S} 2 \mathrm{p}_{3 / 2}$ for the sulfide group, C- $-\underline{S}-\mathrm{C}$ : No. $8,164.4 \mathrm{eV}$ due to $\mathrm{S} 2 \mathrm{p}_{1 / 2}$ for $\mathrm{C}-\underline{\mathrm{S}}-\mathrm{C}$ : No. 9 [28], $167.6 \mathrm{eV}$ due to $\mathrm{S} 2 \mathrm{p}_{3 / 2}$ for $\mathrm{C}-\underline{\mathrm{S}} \mathrm{O}_{2}-\mathrm{C}$ : No. $10,168.5 \mathrm{eV}$ due to $\mathrm{S} 2 \mathrm{p}_{3 / 2}$ for the sulfo group, $\mathrm{C}-\underline{\mathrm{S}} \mathrm{O}_{3} \mathrm{H}$ : No. $11,168.8 \mathrm{eV}$ due to $\mathrm{S}_{2} \mathrm{p}_{1 / 2}$ for $\mathrm{C}-\underline{\mathrm{S}} \mathrm{O}_{2}-\mathrm{C}$ : No. 12 and $170.1 \mathrm{eV}$ due to $\mathrm{S} 2 \mathrm{p}_{1 / 2}$ for $\mathrm{C}-\underline{\mathrm{S}} \mathrm{O}_{3} \mathrm{H}$ : No. 13 (Figure 4f).

Based on these results, we proposed an activation mechanism on the membranes treated with atmospheric pressure low-temperature plasma. The each peak area ratio of $285.3 \mathrm{eV}$ (No. 2 in Figure 4b) and $531.6 \mathrm{eV}$ (No. 4 in Figure 4d) was individually 5 and $14 \%$, which was lower than those of the untreated PES membrane. Two deconvoluted peaks were assigned for $\underline{\mathrm{C}}-\mathrm{SO}_{2}-\underline{\mathrm{C}}$ and $\mathrm{C}-\mathrm{S} \underline{\mathrm{O}}_{2}-\mathrm{C}$, respectively. These findings suggest that metastable argon, which is the most important active species in the present plasma, collides with the oxygen in the sulfonyl group primarily and results in link cleavage, the formation of radicals such as phenyl radical, and deoxidization reactions. After the oxidation reaction proceeded due to air exposure, it was considered that functional groups were formed such as $\mathrm{C}-\mathrm{CH}$ $(-\mathrm{OOH})-\mathrm{C}$ (No. 7 in Figure $4 \mathrm{~d})$ and $\mathrm{C}-\mathrm{SO}_{3} \mathrm{H}$ (No. 11, 13 in Figure 4f) groups. Furthermore, the peak area ratio of the $\pi-\pi^{*}$ shake-up was comparable before and after plasma treatment. It was also suggested that there was low damage and disruption to the benzene ring by treating with plasma under this condition. Therefore, the phenyl radical and radicals originating from the hydroperoxide groups by thermal treatment would be significantly important initiators to induce graft polymerization with AA on the PES membranes.

\subsection{Determination of the human IgG adsorption capacity of affinity membranes}

Adsorption isotherms of the PVDF/PES-g-PAAPrA membranes were constructed to investigate the capacity as affinity membranes. Simultaneously, nonspecific adsorption tests were performed with the PVDF/PES-g-PAA membranes prior to immobilization with Protein A. The equilibrium capacities adsorbed on the membranes $\left(q^{*}\right)$ were calculated via the equilibrium concentration of the human $\operatorname{IgG}$ dissolved in the liquid $\left(c^{*}\right)$ (Figure 5).

The adsorption isotherms constructed with the PVDF/PES-g-PAA-PrA membranes were fitted with the monolayer Langmuir model. On the other hand, as the result of the nonspecific protein adsorption test, the $q^{*}$ of the PVDF membranes with pore sizes of 0.45 and $5.0 \mu \mathrm{m}$ and PES membranes with a pore size $0.45 \mu \mathrm{m}$ were indicated to have relatively low levels of $0.09,0.11$ and 0.12 , respectively. The thermodynamic parameters, which were obtained with the monolayer Langmuir model, are listed in Table 3. In terms of the PVDF-g-PAA-PrA membranes, it can be seen that the maximum binding capacity $\left(q_{\mathrm{m}}\right)$ for a pore size $0.45 \mu \mathrm{m}$ was $0.55 \mathrm{mg} \cdot \mathrm{mL}^{-1}$, which was similar to that with a pore size $5.0 \mu \mathrm{m}$. On the other hand, the equilibrium association constant $\left(K_{\mathrm{a}}\right)$ for a pore size of $5.0 \mu \mathrm{m}$ was $10.6 \cdot 10^{6} \mathrm{~L} \cdot \mathrm{mol}^{-1}$, which was around three times higher than that with a pore size of $0.45 \mu \mathrm{m}$. These findings suggest that there is a relationship between the pore size and $K_{\mathrm{a}}$.

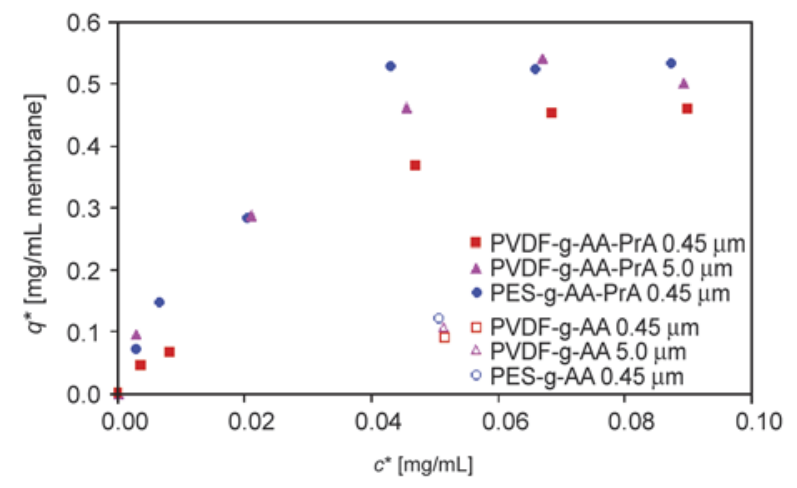

Figure 5. Adsorption isotherms of human $\mathrm{IgG}$ binding to the PVDF (pore size $0.45 \mu \mathrm{m}$ : closed square, $5.0 \mu \mathrm{m}$ : closed triangle) and PES (pore size $0.45 \mu \mathrm{m}$ : closed circle) membranes that were immobilized with Protein A. Open symbols represent the results of the nonspecific adsorption tests. Adsorption conditions: PBS (-), $\mathrm{pH} 7.4$ as an equilibrium buffer, $20^{\circ} \mathrm{C}, 12 \mathrm{~h}$ 
Table 3. Thermodynamic parameters from adsorption isotherms of human IgG on the PVDF and PES membranes immobilized with Protein A, according to the Langmuir monolayer model. Adsorption conditions: PBS (-), pH 7.4 as an equilibrium buffer, $20^{\circ} \mathrm{C}, 12 \mathrm{~h}$

\begin{tabular}{|c|c|c|c|c|}
\hline \multicolumn{1}{|c|}{ Membrane } & $\begin{array}{c}\text { Pore size } \\
{[\boldsymbol{\mu \mathbf { m } ]}]}\end{array}$ & $\begin{array}{c}\boldsymbol{q}_{\mathbf{m}} \\
{\left[\mathbf{m g}_{\mathbf{m}} \mathbf{m L}^{-\mathbf{1}} \mathbf{]}\right.}\end{array}$ & $\begin{array}{c}\boldsymbol{K}_{\mathbf{a}} \\
{\left[\mathbf{L} \cdot \mathbf{m o l}^{-\mathbf{1}} \mathbf{]}\right.}\end{array}$ & $\mathbf{R S Q}$ \\
\hline \multirow{2}{*}{ PVDF-g-PAA-PrA } & 0.45 & 0.55 & $3.3 \cdot 10^{6}$ & 0.955 \\
\cline { 2 - 5 } & 5.0 & 0.56 & $10.6 \cdot 10^{6}$ & 0.992 \\
\hline PES-g-PAA-PrA & 0.45 & 0.76 & $4.9 \cdot 10^{6}$ & 0.997 \\
\hline
\end{tabular}

Membrane affinity matrices require $K_{\mathrm{a}}$ values above $10^{5} \mathrm{~L} \cdot \mathrm{mol}^{-1}$ to ensure efficient adsorption, without risking ligates elution during washing [29]. Compared with capacities of the PVDF/PES-g-PAA-PrA membranes for the same pore size of $0.45 \mu \mathrm{m}$, the $q_{\mathrm{m}}$ of the PES membrane was $0.76 \mathrm{mg} \cdot \mathrm{mL}^{-1}$, which was $38 \%$ higher than that of the PVDF membrane. On the other hand, the $K_{\mathrm{a}}$ of the PES membrane was $4.9 \cdot 10^{6} \mathrm{~L} \cdot \mathrm{mol}^{-1}$, which was similar to that of the PVDF membrane. To further improve these thermodynamic parameters, it would be meaningful to adopt a cross-linking agent that avoids conjugating with the human IgG binding site of Protein A.

As the latest examples of protein purification adopted similar membranes, Sun and $\mathrm{Wu}[30]$ have proposed the bovine serum albumin (BSA) separation using mixed matrix membranes (MMMs) comprising of hydroxyapatite (HAP) inside a PES matrix. The BSA adsorption capacity of HAP particles in MMMs reached a maximum $(29.4 \mathrm{mg} / \mathrm{g}$ membrane $)$ at a $\mathrm{pH}$ of 7. Saufi and Fee [31] have demonstrated that the hydrophobic interaction chromatography MMMs, which consisted of a PVDF membrane using a commercial phenyl resin, had static binding capacities (on the membrane volume basis) of $18.4 \mathrm{mg} \cdot \mathrm{mL}^{-1}$ for $\beta$-lactoglobulin. Hence, by integrating affinity membranes and various MMMs that have a distinct separation mode in the downstream processing of the mAb production, the common issues with packed bed column chromatography, such as complicated packing or operations, could be resolved, leading to reduced production costs.

The ligand densities on the PVDF/PES-g-PAA-PrA membranes were measured to investigate the amount of Protein A immobilized on the membrane surface. The results of the stability tests are also included in Table 4.

Compared with the influence of the PVDF-g-PAAPrA membranes, the ligand density for a pore size
Table 4. Ligand density on the PVDF and PES membranes immobilized with Protein A. Values of ligand densities mean average $(n=3)$. Condition of one cycle: equilibration (PBS (-), pH 7.4, 10 min), adsorption $\left(0.1 \mathrm{mg} \cdot \mathrm{mL}^{-1}\right.$ human $\mathrm{IgG}$ in PBS (-), $\mathrm{pH} 7.4$, $10 \mathrm{~min})$, elution $\left(0.1 \mathrm{~L} \cdot \mathrm{mol}^{-1}\right.$ citric acid buffer, $\mathrm{pH}$ 3.0, $10 \mathrm{~min}$ ), washing (PBS (-), pH 7.4, $10 \mathrm{~min}$ ) and regeneration $(20 \%(\mathrm{v} / \mathrm{v})$ ethanol, $20 \mathrm{~min})$.

\begin{tabular}{|c|c|c|c|c|}
\hline Membrane & $\begin{array}{c}\text { Pore size } \\
{[\boldsymbol{\mu} \mathbf{m}]}\end{array}$ & Cycle & $\begin{array}{c}\text { Ligand density } \\
{\left[\mathbf{m g} \cdot \mathbf{m L}^{-1}\right]}\end{array}$ & S.D. \\
\hline \multirow{3}{*}{ PVDF-g-PAA-PrA } & \multirow{2}{*}{0.45} & - & 0.98 & 0.07 \\
\cline { 2 - 5 } & \multirow{2}{*}{5.0} & 5 & 0.94 & 0.06 \\
\cline { 3 - 5 } & & 5 & 1.42 & 0.10 \\
\hline \multirow{2}{*}{ PES-g-PAA-PrA } & \multirow{2}{*}{0.45} & - & 2.06 & 0.13 \\
\cline { 3 - 5 } & & 5 & 1.98 & 0.04 \\
\hline
\end{tabular}

$5.0 \mu \mathrm{m}$ was $1.42 \mathrm{mg} \cdot \mathrm{mL}^{-1}$, which was $49 \%$ higher than that for a pore size $0.45 \mu \mathrm{m}$. On the other hand, compared with capacities of the PVDF/PES-g-PAAPrA membranes for the same pore size of $0.45 \mu \mathrm{m}$, the ligand density of the PES membrane was $2.06 \mathrm{mg} \cdot \mathrm{mL}^{-1}$, which was approximately two times higher than that of the PVDF membrane. One of the explanations is that the $\mathrm{O} / \mathrm{C}$ atom ratio of the plasmatreated PES membrane was 0.66 (Table 2), which was 3.9 times higher than that of the plasma-treated PVDF membranes (Table 1). Therefore, it was considered that the functional groups necessary for initiating graft polymerizations were generated more on the plasma-treated PES membranes relative to the PVDF membranes. On the other hand, for the PES membrane, the low accessibility to the ligand with the human IgG is suggested by grafting rich polymerization.

The ligand density was determined using a BCA protein assay as described in the experimental section, and this assay is tuned to detect not only active Protein A but also Protein A that is not capable of binding with human $\operatorname{IgG}$ due to the conjugation with the binding site of human IgG. Considering the $q_{\mathrm{m}}$ of the PVDF/PES-g-PAA-PrA membranes for pore size $0.45 \mu \mathrm{m}$ shown in Table 3 , the ratio of active Protein A modified on the PVDF-g-PAA-PrA membrane would be higher than that of the PES-g-PAAPrA membrane.

As a recent related to the study of fabricating functional polymers, Starke et al. [32] have introduced a technique for covalent immobilization of trypsin on hydrophilic PVDF and PES membranes both with $0.22 \mu \mathrm{m}$ pores using electron beam irradiation (150 kGy). Comparing the trypsin concentration 
and activity of these immobilized membranes, the PES membrane showed the higher concentration of $3.48 \mu \mathrm{g} \cdot \mathrm{cm}^{-2}$ and an activity of $0.49 \mathrm{nmol} \cdot \mathrm{min}^{-1}$ in the case of the PVDF membrane $\left(2.46 \mu \mathrm{g} \cdot \mathrm{cm}^{-2}\right.$ and $\left.0.36 \mathrm{nmol} \cdot \mathrm{min}^{-1}\right)$. However, the enzyme efficiency of trypsin, which was calculated as a quotient of the maximum released substrate per trypsin concentration, turned out to be $5.8 \mathrm{nmol} \cdot \mathrm{cm}^{2} \cdot \mathrm{gg}^{-1}$ of the PVDF membrane and was higher than the $3.2 \mathrm{nmol} \cdot \mathrm{cm}^{2} \cdot \mu \mathrm{g}^{-1}$ with the PES membrane described above.

In the results of the stability test, it was confirmed that the ligand densities were comparable, and Protein A was immobilized on the membrane surface rigidly. Castilho et al. [13] have reported that the ligand density of poly (vinyl alcohol)-coated membranes, which were the most suitable for IgG purification among the membranes tested in the work, was $4.66 \mathrm{mg}$ protein $\mathrm{A} / \mathrm{mL}$ membrane. In summary, it was found that the PVDF/PES-g-PAA-PrA membranes were immobilized with Protein A rigidly, and had the properties of an affinity membrane.

\subsection{Membrane morphology}

It is important to understand whether the microporous structure of the membranes was retained after the plasma treatment and subsequent graft polymerization were conducted. Figure 6 shows the SEM images, obtained with a $3000 \times$ magnification. Figures $6 \mathrm{a}-6 \mathrm{c}$ represent the untreated PVDF for pore sizes of 0.45 and $5.0 \mu \mathrm{m}$, and the PES membrane for a pore size of $0.45 \mu \mathrm{m}$, respectively. Figures $6 \mathrm{~d}-$ $6 \mathrm{f}$ show the plasma-treated membranes. The plasmatreated PVDF membrane fibers of the scaffolds for a pore size of $5.0 \mu \mathrm{m}$, shown in Figure $6 \mathrm{e}$, maintained the macrovoid formation as well as the untreated PVDF membrane. On the other hand, the plasma-

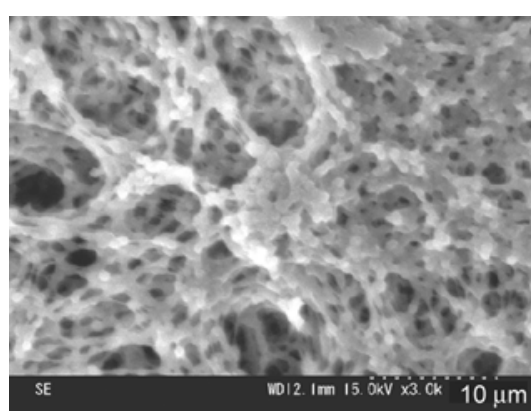

a)

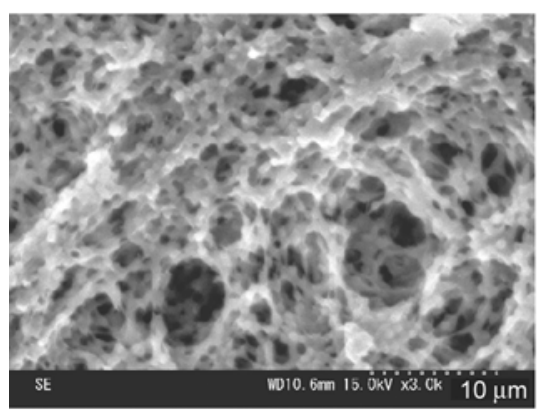

d)

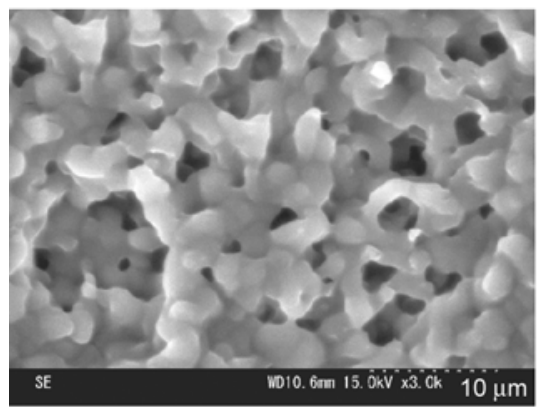

g)

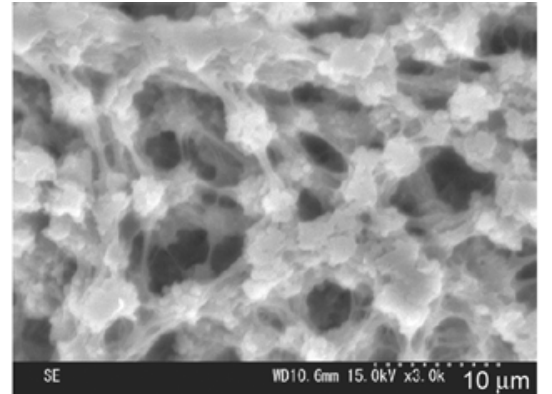

b)

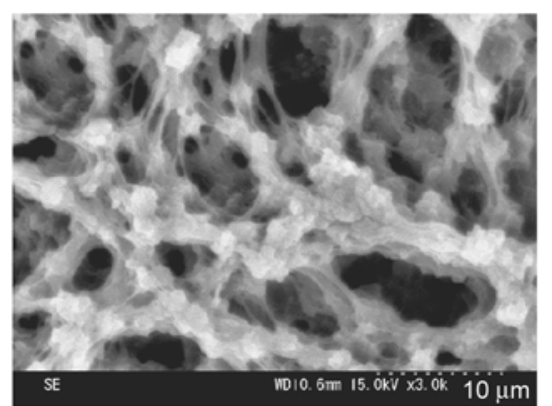

e)

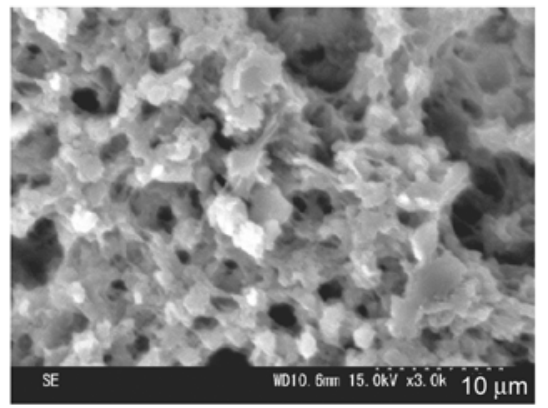

h)

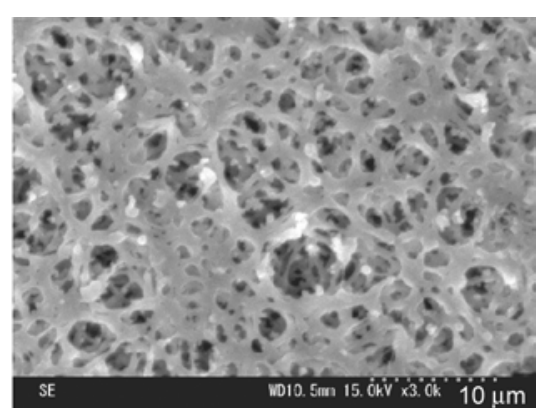

c)

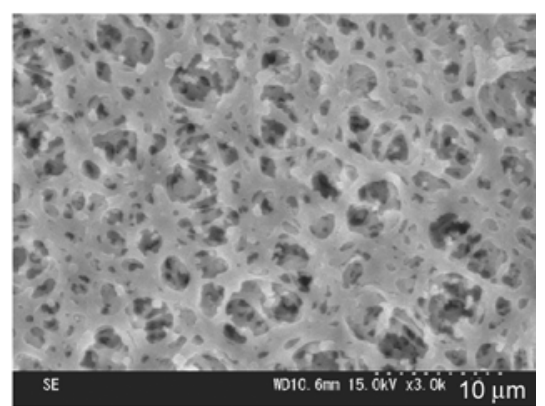

f)

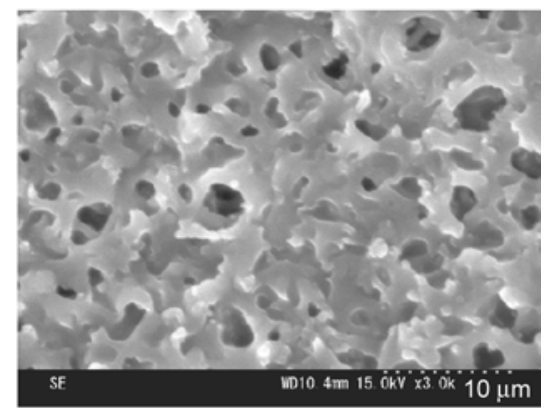

i)

Figure 6. SEM images of PVDF (pore size $0.45 \mu \mathrm{m}(\mathrm{a}, \mathrm{d}, \mathrm{g})$ and $5.0 \mu \mathrm{m}(\mathrm{b}, \mathrm{e}, \mathrm{h})$ ) and PES (c, f, i: pore size $0.45 \mu \mathrm{m}) \mathrm{mem}-$ brane surfaces. Untreated (a, b, c), treated with argon plasma (d, e, f; treatment: $\pm 4.0 \mathrm{kVp}-\mathrm{p}, 180 \mathrm{~s})$ and grafted with AA (g, h, i; treatment: $\left.20 \%(\mathrm{v} / \mathrm{v}) \mathrm{AA}, 70^{\circ} \mathrm{C}, 20 \mathrm{~min}\right)$. The argon plasma was treated from the above of these membranes. 
treated PVDF and PES membrane fibers for a pore size of $0.45 \mu \mathrm{m}$, shown in Figures $6 \mathrm{~d}$ and $6 \mathrm{f}$, had grown slightly thicker than those for each untreated membrane surface. Figures $6 \mathrm{~g}-6 \mathrm{i}$ show the PVDF/ PES-g-PAA membranes. The PVDF/PES-g-PAA membranes with a pore size of $0.45 \mu \mathrm{m}$ were densely modified with PAA. By contrast, the PVDF-g-PAA membrane for a pore size of $5.0 \mu \mathrm{m}$ definitely retained the macrovoid formation (Figure 6h). These findings clearly indicate that it is effective to apply membranes with a pore size of $5.0 \mu \mathrm{m}$ to maintain the high porosity and accessibility as affinity membranes.

\section{Conclusions}

We have described the characterization of Protein Aimmobilized PVDF and PES membranes. The results of surface property tests on the membranes activated by argon plasma confirmed several functional groups such as hydroperoxide, sulfide and sulfo groups, and we proposed the activation mechanism on polymeric substrates. These findings suggest that the phenyl radical and radicals originating from hydroperoxide groups by thermal treatment are the important precursors to induce graft polymerization with AA on the PES membranes. The porosity of the membrane scaffold was preserved after the plasma treatment. The PVDF membrane for a pore size of $5.0 \mu \mathrm{m}$ definitely retained the macrovoid formation after the graft polymerization. Protein A was successfully immobilized on the polymer-modified membranes. The adsorption capacities of the Protein A-immobilized membranes were determined and shown to be dependent on the pore size. The ligand density of the Protein A-immobilized PES membranes was approximately two times higher than that of the Protein A-immobilized PVDF membranes. Taken together, we conclude that the atmospheric pressure low-temperature plasma is an excellent tool for activation on the PVDF and PES membranes given the simplicity and effectiveness of this tool, and these polymers are candidates for affinity media for human IgG separation.

\section{References}

[1] Dargaville T. R., George G. A., Hill D. J. T., Whittaker A. K.: High energy radiation grafting of fluoropolymers. Progress in Polymer Science, 28, 1355-1376 (2003). DOI: $10.1016 / \mathrm{S} 0079-6700(03) 00047-9$
[2] Johns K., Stead G.: Fluoroproducts - The extremophiles. Journal of Fluorine Chemistry, 104, 5-18 (2000).

DOI: 10.1016/S0022-1139(00)00251-7

[3] Liu F., Hashim N. A., Liu Y., Abed M. R. M., Li K.: Progress in the production and modification of PVDF membranes. Journal of Membrane Science, 375, 1-27 (2011).

DOI: 10.1016/j.memsci.2011.03.014

[4] Kull K. R., Steen M. L., Fisher E. R.: Surface modification with nitrogen-containing plasmas to produce hydrophilic, low-fouling membranes. Journal of Membrane Science, 246, 203-215 (2005).

DOI: $10.1016 /$ j.memsci.2004.08.019

[5] Zhu L-P., Zhu B-K., Xu L., Feng Y-X., Liu F., Xu Y-Y.: Corona-induced graft polymerization for surface modification of porous polyethersulfone membranes. Applied Surface Science, 253, 6052-6059 (2007). DOI: 10.1016/j.apsusc.2007.01.004

[6] Rahimpour A.: UV photo-grafting of hydrophilic monomers onto the surface of nano-porous PES membranes for improving surface properties. Desalination, 265, 93-101 (2011). DOI: $10.1016 /$ j.desal.2010.07.037

[7] Steuck M. J.: Porous membrane having hydrophilic surface and process. U.S. Patent 4618533, USA (1986).

[8] Mezhirov M., Yeh E. B., Sale R.: Method for preparing hydrophilic polyethersulfone membrane. U.S. Patent 8425814 B2, USA (2013).

[9] van Reis R., Zydney A.: Bioprocess membrane technology. Journal of Membrane Science, 297, 16-50 (2007). DOI: 10.1016/j.memsci.2007.02.045

[10] Nasef M. M., Güven O.: Radiation-grafted copolymers for separation and purification purposes: Status, challenges and future directions. Progress in Polymer Science, 37, 1597-1656 (2012).

DOI: $10.1016 /$ j.progpolymsci.2012.07.004

[11] Ulbricht M.: Advanced functional polymer membranes. Polymer, 47, 2217-2262 (2006). DOI: $10.1016 /$ j.polymer.2006.01.084

[12] Han M. J., Baroña G. N. B., Jung B.: Effect of surface charge on hydrophilically modified poly(vinylidene fluoride) membrane for microfiltration. Desalination, 270, 76-83 (2011). DOI: 10.1016/j.desal.2010.11.024

[13] Castilho L. R., Deckwer W-D., Anspach F. B.: Influence of matrix activation and polymer coating on the purification of human IgG with protein A affinity membranes. Journal of Membrane Science, 172, 269277 (2000). DOI: $10.1016 / \mathrm{S} 0376-7388(00) 00343-4$

[14] Shukla A. A., Hubbard B., Tressel T., Guhan S., Low D.: Downstream processing of monoclonal antibodies - Application of platform approaches. Journal of Chromatography B, 848, 28-39 (2007). DOI: $10.1016 /$ j.jchromb.2006.09.026 
[15] Low D., O’Leary R., Pujar N. S.: Future of antibody purification. Journal of Chromatography B, 848, 4863 (2007).

DOI: $10.1016 /$ j.jchromb.2006.10.033

[16] Chu P. K., Chen J. Y., Wang L. P., Huang N.: Plasmasurface modification of biomaterials. Materials Science and Engineering R: Reports, 36, 143-206 (2002). DOI: 10.1016/S0927-796X(02)00004-9

[17] Müller M., Oehr C.: Plasma aminofunctionalisation of PVDF microfiltration membranes: comparison of the in plasma modifications with a grafting method using ESCA and an amino-selective fluorescent probe. Surface and Coatings Technology, 116-119, 802-807 (1999).

DOI: $10.1016 / \mathrm{S} 0257-8972(99) 00268-6$

[18] Tendero C., Tixier C., Tristant P., Desmaison J., Leprince P.: Atmospheric pressure plasmas: A review. Spectrochimica Acta Part B: Atomic Spectroscopy, 61, 230 (2006).

DOI: $\underline{10.1016 / \mathrm{j} . \mathrm{sab} .2005 .10 .003}$

[19] Akashi N., Kuroda S.: Protein immobilization onto poly(vinylidene fluoride) microporous membranes activated by the atmospheric pressure low temperature plasma. Polymer, 55, 2780-2791 (2014).

DOI: 10.1016/j.polymer.2014.04.029

[20] Momtaz M., Dewez J. L., Marchand-Brynaert J.: Chemical reactivity assay and surface characterization of a poly(vinylidene fluoride) microfiltration membrane ("Durapore DVPP"). Journal of Membrane Science, 250, 29-37 (2005).

DOI: $10.1016 /$ j.memsci.2004.10.011

[21] Persson K. M., Capannelli G., Bottino A., Trägårdh G.: Porosity and protein adsorption of four polymeric microfiltration membranes. Journal of Membrane Science, 76, 61-71 (1993).

DOI: $10.1016 / 0376-7388(93) 87005-\mathrm{V}$

[22] Langmuir I.: The adsorption of gases on plane surfaces of glass, mica and platinum. Journal of the American Chemical Society, 40, 1361-1403 (1918).

DOI: $10.1021 / \mathrm{ja} 02242 \mathrm{a} 004$

[23] Castilho L. R., Anspach F. B., Deckwer W-D.: Comparison of affinity membranes for the purification of immunoglobulins. Journal of Membrane Science, 207, 253-264 (2002).

DOI: $10.1016 / \mathrm{S} 0376-7388(02) 00257-0$
[24] Huse K., Böhme H-J., Scholz G. H.: Purification of antibodies by affinity chromatography. Journal of Biochemical and Biophysical Methods, 51, 217-231 (2002). DOI: $10.1016 / \mathrm{S} 0165-022 \mathrm{X}(02) 00017-9$

[25] Hidzir N. M., Hill D. J. T., Taran E., Martin D., Grøndahl L.: Argon plasma treatment-induced grafting of acrylic acid onto expanded poly(tetrafluoroethylene) membranes. Polymer, 54, 6536-6546 (2013). DOI: $10.1016 /$ j.polymer.2013.10.003

[26] Lee Y. M., Shim J. K.: Plasma surface graft of acrylic acid onto a porous poly(vinylidene fluoride) membrane and its riboflavin permeation. Journal of Applied Polymer Science, 61, 1245-1250 (1996).

DOI: $10.1002 /($ SICI) 1097-4628(19960822)61:8<1245 $\because$ AID-APP2>3.0.CO;2-K

[27] Huang F. L., Wang Q. Q., Wei Q. F., Gao W. D., Shou H. Y., Jiang S. D.: Dynamic wettability and contact angles of poly(vinylidene fluoride) nanofiber membranes grafted with acrylic acid. Express Polymer Letters, 4, 551-558 (2010).

DOI: $10.3144 /$ expresspolymlett.2010.69

[28] Wavhal D. S., Fisher E. R.: Hydrophilic modification of polyethersulfone membranes by low temperature plasma-induced graft polymerization. Journal of Membrane Science, 209, 255-269 (2002).

DOI: $10.1016 / \mathrm{S} 0376-7388(02) 00352-6$

[29] Beeskow T. C., Kusharyoto W., Anspach F. B., Kroner K. H., Deckwer W-D.: Surface modification of microporous polyamide membranes with hydroxyethyl cellulose and their application as affinity membranes. Journal of Chromatography A, 715, 49-65 (1995).

DOI: 10.1016/0021-9673(95)00540-4

[30] Sun J., Wu L.: Polyether sulfone/hydroxyapatite mixed matrix membranes for protein purification. Applied Surface Science, 308, 155-160 (2014).

DOI: $10.1016 /$ j.apsusc.2014.04.123

[31] Saufi S. M., Fee C. J.: Mixed matrix membrane chromatography based on hydrophobic interaction for whey protein fractionation. Journal of Membrane Science, 444, 157-163 (2013).

DOI: $10.1016 /$ j.memsci.2013.05.007

[32] Starke S., Went M., Prager A., Schulze A.: A novel electron beam-based method for the immobilization of trypsin on poly(ethersulfone) and poly(vinylidene fluoride) membranes. Reactive and Functional Polymers, 73, 698-702 (2013).

DOI: $10.1016 /$ j.reactfunctpolym.2013.02.013 